\title{
Preparing for the next pandemic by creating Canadian Immunization Services
}

\author{
Kumanan Wilson MD MSc, Graham Sher MB BCh, Jane Philpott MD MPH
}

- Cite as: CMAJ 2021 July 19;193:E1092-3. doi: 10.1503/cmaj.210670

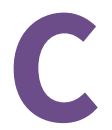

anada's federal auditor general released their first report on Canada's response to the COVID-19 pandemic on Mar. 25, 2021. The report identified systemic failures that date back decades, failings that have been documented in 3 previous reports that identified problems in how the federal government, provinces and territories work together. ${ }^{1}$ There will be many more pandemic postmortems that arrive at the same conclusion, just as they did after the outbreak of severe acute respiratory syndrome (SARS). ${ }^{2}$ There will be calls for change, for developing new covenants between our orders of government, and promises of a new era of cooperation will be made. Sadly, after an initial flurry of activity, nothing substantive is likely to change.

At the root of this "Groundhog Day" scenario lies the reality that Canada is a highly decentralized federation and much of the responsibility for managing public health is at the provincial and territorial level. The federal government has generally had 2 options available to develop pan-Canadian approaches: the use of legislation or conditional funding to compel provinces and territories to align themselves or a more collaborative approach. The approach taken by the federal government to manage public health has historically been to collaborate rather than dictate, characterized by a reluctance to use the Emergencies Act to address public health emergencies. ${ }^{3}$ This is partly out of recognition that without provincial and territorial co-operation, federal mandates will be ineffective and that, in practice, the responsibility for managing threats to public health lies at the provincial and territorial level. This collaborative approach has limits, however, as exemplified by the lack of progress in developing a harmonized, Canada-wide approach to pandemics. ${ }^{4}$

However, another option for the federal government to consider exists: formal interprovincial and interterritorial collaboration. ${ }^{5}$ This approach was successful after one of Canada's biggest public health crises, the tainted blood scandal. Canadian Blood Services, which was created after the Commission of Inquiry on the Blood System in Canada (Krever Inquiry), is an independent not-for-profit corporation, funded by participating provinces and territories, and mandated to deliver integrated transfusion and transplantation products and services. The provincial and territorial ministers of health (excluding Quebec) serve as the members ("shareholders") of the corporation and appoint an independent board of directors to

\section{KEY POINTS}

- Canada's response to the COVID-19 pandemic has been plagued by many of the same challenges that have affected its response to public health threats over the past 2 decades.

- These challenges largely relate to how the federal, provincial and territorial governments work together in a federal system in which responsibility for public health duties is provincial, territorial or local, but pan-Canadian coordination is critical.

- Creating a Canadian Immunization Services using the model for the Canadian Blood Services could address historical challenges related to variability in immunization practices and sharing of data across Canada.

oversee governance. The governance framework ensures operational independence of the corporation. Quebec opted out and has its own operator (Héma-Québec), but there is strong collaboration between the 2 organizations, both of which are regulated by Health Canada under the federal Food and Drugs Act. By most measures, the reform of the Canadian blood system has been a success. ${ }^{6}$

This model could be applied to Canada's fragmented immunization systems. ${ }^{7}$ Although there have been efforts at coordination, each province and territory creates its own vaccination schedules and keeps track of who has been vaccinated in its own way. Provincial and territorial databases often use different terminology, which makes it challenging to coordinate pan-Canadian disease surveillance and mass immunization responses - not to mention the practical impact on patient care when people move from 1 region to another.

Creating Canadian Immunization Services using the model of Canadian Blood Services could address some of these challenges. The federal minister of health would work with the provinces and territories to develop a memorandum of understanding to outline roles and responsibilities for the new entity. The federal government could participate in the entity as an equal partner, given the importance of vaccination to Canadians under its jurisdiction. The participating governments would have control over Canadian Immunization Services and oversee the organization as its corporate members. They would fund the entity to procure all vaccines in bulk on their behalf. Vaccine surveillance 
and management of the vaccine supply chain would be facilitated by having a single entity manage vaccination on behalf of participating members, using a common data standard to facilitate interprovincial and interterritorial data sharing. ${ }^{8}$ The entity would be able to consolidate expertise from across the country, unencumbered by governmental hiring rules.

There would be some challenges to this solution. The entity would need to work with provincial and territorial members to determine the best way to distribute and manage vaccine deliveries and administration because each province and territory will have existing approaches. Determining how scarce vaccines are to be allocated in the event of a pandemic could be challenging, and rules could be established to guide this during the interpandemic period. Provinces and territories may opt out, analogous to Quebec creating its own blood system operator. However, the federal government could incentivize joining the entity by providing support for research and development. Responses do need to be customized for local environments (e.g., accommodation for the different approaches to vaccine provision used by the provinces and territories.)

Canadian Immunization Services, if successful, could go on to serve as a model for other public health functions that have struggled under the current federal approach to public health, including disease surveillance. ${ }^{9}$ The approach would likely work best for activities for which responsibilities primarily fall under provincial and territorial jurisdiction, but there is a need for pan-Canadian harmonization. If we hope for public health to be better prepared for the next pandemic, now is the time to implement needed changes.

\section{References}

1. Attaran A. A legislative failure of epidemic proportions. CMAJ 2008;179:9-10.

2. Goel V. What do we do with the SARS reports? Healthc $Q$ 2004;7:28-30.

3. Attaran A, Wilson K. A legal and epidemiological justification for federal authority in public health emergencies. McGill Law J 2007;52:381-414.

4. Review of Canada's initial response to the COVID-19 pandemic. Ottawa: Canadian Public Health Association; 2021. Available: https://www.cpha.ca/review-canadas -initial-response-covid-19-pandemic (accessed 2021 June 7).

5. Courchene T. ACCESS: a convention on the Canadian economic and social systems. In: Assessing ACCESS. Towards a new social union: Proceedings of the Symposium on the Courchene Proposal. Kingston (ON): Institute of Intergovernmental Relations, Queen's University; 1997. Available: https://www.queensu.ca/iigr/sites/ webpublish.queensu.ca.iigrwww/files/files/pub/archive/books/AssessingAccess -TowardsaNewSocialUnion.pdf (accessed 2021 Apr. 6).

6. Wilson K. The Krever Commission: 10 years later. CMAJ 2007;177:1387-9.

7. Eggertson L. Experts call for national immunization registry, coordinated schedules. CMAJ 2011;183:E143-4.

8. Canadian Immunization Registry Functional Standards (IRFS) 2020-2024: recommendations from the Canadian Immunization Registry and Coverage Network (CIRC). Ottawa: Public Health Agency of Canada; modified 2021 Jan. 6. Available: https://www.canada.ca/en/public-health/services/publications/vaccines -immunization/canadian-immunization-registry-functional-standards-2020 -2024.html (accessed 2021 June 7).

9. Webster P. National electronic disease surveillance: a dream delayed. CMAJ 2013;185:E365-6.
Competing interests: Kumanan Wilson was a consultant to the auditor general's report on the response to the pandemic and was a previous consultant to the 2008 report on health surveillance. He has been a consultant to the World Health Organization on International Health Regulations, was a member of the Canadian Blood Services Scientific and Research Advisory Committee, is a member of the data safety advisory board for Medicago, and is founder and CEO of CANImmunize Inc. Jane Philpott is a former federal minister of health and a member of the boards of the Canadian Institutes of Health Research Institute of Population and Public Health, SE Health, Elentra and Kingston Health Sciences Centre. Graham Sher is the CEO of Canadian Blood Services. No other competing interests were declared.
This article has been peer reviewed.

Affiliations: Department of Medicine (Wilson), University of Ottawa; Bruyère Research Institute (Wilson); Ottawa Hospital Research Institute (Wilson); Canadian Blood Services (Sher), Ottawa, Ont.; Department of Family Medicine (Philpott), Queen's University, Kingston, Ont.

Contributors: All of the authors contributed to the conception of the article, wrote and revised it critically for important intellectual content, gave final approval of the version to be published and agreed to be accountable for all aspects of the work.

Content licence: This is an Open Access article distributed in accordance with the terms of the Creative Commons Attribution (CC BY-NC-ND 4.0) licence, which permits use, distribution and reproduction in any medium, provided that the original publication is properly cited, the use is noncommercial (i.e., research or educational use), and no modifications or adaptations are made. See: https://creativecommons. org/licenses/by-nc-nd/4.0/

Acknowledgement: Funding was received from a Canadian Institutes of Health Research grant.

Disclaimer: Jane Philpott is a member of the Editorial Advisory Board for CMAJ and was not involved in the editorial decision-making process for this article. Kumanan Wilson is the spouse of Kim Barnhardt (Senior strategist, communications and partnerships for (MAJ), who was not involved in the editorial decisionmaking process for this article.

Correspondence to: Kumanan Wilson, kwilson@ohri.ca 